\title{
PLANNING AND URBAN GROWTH. WHAT TO DO WITH URBANIZED VACANT AREAS IN THE LAND OF VALENCIA?
}

\author{
F. GAJA I DÍAZ \\ Department of Urbanism, Universitat Politècnica de València, Spain.
}

\begin{abstract}
In 1996, an expanding real estate property cycle of unusual magnitudes began in the Kingdom of Spain, to abruptly cease in 2007. Its economic, social and political logic has been to this day widely studied, but instead the contribution of urban planning as a driver and impeller of proposals of unviable urban overgrowth has received scant attention. In this paper, we shall consider the role played by urban planning with disparate proposals in the so-called construction bubble. By studying relevant case studies, we will evidence the impact that of over planning has had on the environment and natural resources. In 1994, it was approved for the Community of Valencia, a ground-breaking law, that allowed real estate agents to develop areas in which they had not any property even against the opinion and the will of the landowners. The facilities given to developers, in a context of abuse and corruption, have taken their toll after the bursting of the housing bubble. Our goal is to analyse the effects and consequences of these actions: the destruction of the landscape, the consumption of natural resources beyond their capacity for regeneration, the development of areas that today remain vacant, with special emphasis on the latter. Keywords: empty city, environmental impact, hegemony in urban development, planning, urban land.
\end{abstract}

\section{INTRODUCTION}

Between 1996 and 2007 in the Spanish State a cycle of hyper construction with no precedents was unleashed. It has become a popular topic the certain fact that in that period were built in the State more homes than Germany and France all together [1]. It should be noted, however, that what happened in that decade long goes far beyond a building boom since the construction bubble also affected the production of urban land, infrastructures and facilities. In Gaja [2], I have highlighted the multiple nature of this boom. In this paper, I shall focus on the analysis of the process of overdeveloping land, considering its impacts, such as the ecological, social, administrative and economic ones.

What happened in the so-called "Prodigious Decade", the real estate tsunami or the "Brick Rush" (1996-2007), can be described as a process of metastatic growth in the construction, which in its fall has come to affect the banking sector; and, conversely, the overgrowth of construction activity would not have been possible without an easy, abundant and cheap financing, that is to say without a parallel credit bubble. But with the financial factor must be taken into account together with others that also helped to inflate the building bubble, i.e.: (i) the behaviour of the Public Administration; (ii) a plentiful private demand; (iii) the social preference for home property instead of renting; and last but not least, (iv) urban planning, in which we will focus specially.

The overproduction construction cycle is rooted on the economic model adopted after the civil war (1936-1939). It relies on three factors: construction, tourism and the remittances of 
emigrants. The first two linked in closed symbiosis: tourism encouraged and pulled construction, meanwhile urbanized spaces and buildings were produced to accommodate the flocks of visitors coming from northern Europe. The remittances from emigrants have had a very limited and declining role after the seventies, and even reverse on in the nineties and in the first decade of the century XXI.

The development of the construction sector as well as the tourism activity cannot be understood without the impulse and the stimulus of the public administration throughout six decades. The public sector holds a leading role, providing facilitating loans, hiring works and projects, or even promoting them directly, developing urban land, and generously subsidizing the "brick", encouraging house property as the form of tenancy absolutely dominant, setting prices, regulating the activity for avoiding the appearance of unwanted competitors, eliminating environmental requirements and social security contributions,... and quieten down the opposition when necessary,... in brief being an essential agent in this enormous process from expansion of the sector, not to let mention the awesome process of capital accumulation that happened at the same time. This model kept on working, with ups and downs, until September 2007 when mortgages subprime crisis exploded in the USA. Few people could think that this episode would mark the burst of the housing bubble. The immediate outlook was devastating, a crumbling card castle: collapse of the construction industry, financial bailout, evictions, and rapid increase in unemployment.... A social crisis, which, despite what the official propaganda may say, has not yet come to a solution. Let's consider the consequences of this singular and unbalanced period.

\section{VACANT CITY}

It is difficult to establish a detailed inventory of the production of construction boom because available data is extremely vague and unreliable, and besides has not been sorted out into the areas of activity that I have distinguished. In any case, all stock takings seem to show a panorama characterized by an oversized, underutilized and difficult to digest amount of real estate properties. With regard to urban land, being the result of overproduction cycle, a huge amount of this land that nowadays remains largely empty. We shall restrict the object of our study to developed land that has not been built or only partially or very small extent, what we have named the vacant or empty city.

\subsection{How the city is built (in the framework of the Spanish State)}

To understand why so much land was urbanized it is necessary to briefly explain the framework in which this process took place. The construction of urban space, as currently it is regulated in the Spanish State, dates from 1956 with the passing of the so-called Land Act (hereinafter LS 1956). Four distinct stages were set on to develop any piece of land; all of them have remained until today: (i) First of all, rural land should be characterized as "Able to be Developed" by a General Plan and a Development Plan. We shall name this resulting territory as planned land; (ii) in the second phase, the "management" stage, several economic-legal actions done to adjust the structure of land ownership to the previously approved design management. The product thus obtained is managed land; (iii) when the territory, which has not yet been physically transformed, is now constructed, urbanized land is obtained; (iv) finally, the resulting plots can now be built, thus producing consolidated or urban land.

Quite often some urban land balance do not distinguish these four stages, and mixing and confusing planned land with managed land or the finally urbanized one, and therefore getting oversized calculations. 


\subsection{A noiseless revolution: the LRAU (1994) and its heirs}

Production of urban land from 1956 to 1994 was largely blocked because the LS 1956 granted the exclusive management of the process to the landowners. Only they could undertake the actions leading to the development of land; but most of the rural land landlords were neither really developers nor entrepreneurs, but simply rentiers waiting for a buyer willing to pay the exorbitant figures demanded by land that remained physically agricultural, but to which planning had "given" status as developable.

As a result of this accurate analysis, the government of land of Valencia adopted in 1994 a new regulation (confined in the beginning just to the autonomous community) that allowed developers who had not any property in an area to be urbanize it, even against the will of landowners. This figure was designated as the "development agent", a highly controversial one, which was strongly criticized by the European Union in three reports dating, the first one, the Kessler Report from 2004 [3]; the second one the Fourtou Report from 2005 [4], and the third one the Auken Report from 2009 [5], besides a European Parliament resolution adopted on 13 June 2006. All of them agreed to consider that the dynamic started by the LRAU 94 was "unfortunate", and that it would have severe impacts of all kinds, as it has been. But it is not about these abuses or the change in hegemony (the landowners had before "abused" of their position by clearly speculating), or the missed opportunity to establish a more socially fair and progressive model, that I want to talk about but on the rise in the production of urbanized land that these new rules encouraged.

\subsection{Hyper planning}

In addition to the new legislation, we must add another factor to explain the real estate cycle of overproduction: the contribution of oversized Master Plans, a common and traditional practice. From sixties onward, Master Plans were drafted and approved, with very overestimate growth forecasts, thus becoming a usual routine. It was felt, with some basis, that most of the areas of expansion were not going to be urbanized, and therefore was convenient enlarge them, knowing that few of them would go from paper to reality. Thus, when in the late twentieth century, an expansive conjuncture suddenly broke in, planning a flammable, explosive material, which nobody had bothered to adjust to reasonable demands.

\subsection{The urban land bubble, an outcome}

How much land has been planned - managed - urbanized or built in this overproduction cycle? If it is difficult to know how many dwellings were built, houses that today remain unsold, to estimate the amount of unoccupied land it is even more difficult. Considering the four categories we have established, only for the third can we have reliable data, obtained from by satellite images. In this regard, there are three available sources: i) the OSE (acronym for "Observatorio de la Sostenibilidad en España", Observatory of Sustainability in Spain); ii) the SIOSE (acronym for "Sistema de Información sobre Ocupación del Suelo de España", Information System on Land Occupation in Spain); and the data from the European Environment Agency.

The OSE, one of the most reliable sources, from 2004 to 2012 published annual reports including accounts of "artificialized" surfaces, assessed from data supplied by the satellite Corinne Land Cover. The OSE applied an unusual concept in urbanism: "artificialized terrain," comprising all rural land (whether agricultural or natural) no transformed by human 
action. In this atypical category strange situations were included, while the industrial or tertiary plots were separated from the rest urban land. Despite these objections, its data are certainly useful, and allows to take account of how between 1997 and 2005, State-wide 294,712 hectares were urbanized; an increase of $49.92 \%$, in just 8 years [6].

Estimates of the SIOSE do not exactly match those of the OSE, which is not surprising because their methods and categories are different, but they give an order of magnitude fairly approximate. Finally, the most recent data (June 2013), it is provided by the European Environment Agency, based on the information provided also by the satellite Corinne Land Cover. According to this source, State-wide between 2000 and 2006, 25,406 hectares per year were urbanized (no more and no less than $23.5 \%$ of the European artificialized surface). By way of comparison, let's say in the same period, France urbanized 13,156 hectares per year, Germany hectares per year, and Italy has 7,280 hectares per year, all of them having a much larger population [7].

In short, we can say that during the real estate boom some 300,000 hectares, according to OSE, or 250,000 according to the EEA, were urbanized; an enormous area that we cannot be expected to be built, thus remaining empty for a horizon of at least 25 years or a generation. Let's consider the impact of this "empty city".

As regards of the autonomous region of Valencia, the total land classified as developable or unconsolidated estimated by Burriel [8] amounted to 51,999 hectares, somehow a figure much lower than the 80,000 recognized as "plots" by the Director of Planning of the Autonomous Government [9], although these sources make no distinction, as we propose, between urbanized or planned land. Yet fewer sources or authors will have detailed and reliable data on the aggregate amount of urbanized vacant land, which is the most crucial problem, considering its burdensome reversibility. From the SIU (acronym for "Sistema de Información Urbana", Urban Information System), also Burriel [8] has been estimated the total amount for the Valencian region in 25,207 hectares, but without making any distinction depending on the degree of occupation.

\subsection{Impacts on sustainability of hyper urbanization}

To assess the sustainability of urban development, we will adopt a broad definition adding to the ecological standpoint, social and economic reflections. This expanded definition of sustainability that goes beyond the purely environmental framework is already common in assessing impacts. Thus, from this perspective, the impact of hyper-urbanization on the

Table 1: Land use in Spain from 1997 to 2005. Source: OSE. 2.014.92.

\begin{tabular}{lcc}
\hline Category & $\begin{array}{c}1997 \\
\text { (Hectares) }\end{array}$ & $\begin{array}{c}2005 \\
\text { (Hectares) }\end{array}$ \\
\hline Continuous urban fabric (residential) & 253,136 & 293,446 \\
Discontinuous urban fabric (residential) & 230,505 & 338,996 \\
Industrial or commercial areas & 76,624 & 146,580 \\
Areas under construction & 16,629 & 71,261 \\
Urban greenery & 4,515 & 6,681 \\
Sports \& recreational areas & 8,964 & 28,121 \\
Total & 590,373 & 885,085 \\
\hline
\end{tabular}


sustainability of a territory can be examined into four fields. First of all, the strictly ecological burdens (consumption of resources, with special attention to water in semi-arid environments such as the Mediterranean basin, but also the materials used in its construction, the destruction of landscape, ...). Another kind of repercussions can be grouped under the label of social, including here economic (debt, unemployment, opportunity cost...) and cultural (such as the degradation of social values, not to mention the costs and collateral damage from corruption) ones. We must add the impacts on public administrations, such as the cost of maintaining the empty city, which by law has be paid by them. In empty developments municipalities are bound to ensure the provision of urban services; for instance, street lighting and cleaning, security, even in some cases transportation, while tax revenues (basically property taxes) is far from covering the costs of providing those services. Finally, let's not forget the sociopolitical factor, with the subjugation and loss of Public Authority, subordinated to the interests of private sector.

\section{ALTERNATIVES TO THE EMPTY CITY}

What alternatives can be raised to reduce the costs and impacts of the empty city, given its enormous size? The first one, which has been adopted institutionally, is to "wait and see". Let time pass until the market digests the huge housing stock. In Gaja [10], I discussed this option and tried to prove that it was impossible. Given the current rate of demand, it may take 25 years or more for the housing stock to be significantly reduced. A much longer period, almost incalculable, for urban land. Besides we have not considered in addition to the impacts previously mentioned, the deterioration already ostensible in many areas of "empty city".

"Better times will come", "the market will finish digesting the stock of urban land"... these are expressions that you hear in the media, even among academics and qualified professionals. But the option to "wait and see is" based on a conceptual error which is to believe that this is a cyclical crisis, when its nature is systemic, being the end of an exhausted model based on continuous and supposedly infinite growth. By the mere passage of time things will not return to "normal" stage, understood as the situation prior to the crisis. Furthermore, it is an option characterized by a strong passivity, proactive alternatives are needed.

The second option, less widespread, but the most obvious and immediate, it is to reuse the empty developments, changing the uses where possible, but maintaining the bet on its market absorption. Giving all kinds of economic, legal, fiscal, administrative facilities ... whatever it may be convenient just to encourage the reuse of empty land. Let's be clear, this option is neither always feasible nor desirable. Without dismissing it at the same time, its implementation would require a previous and detailed inventory of vacant land and decide which developments can be "saved" and which not, under any circumstances.

In those cases where reuse is discounted, the only remaining alternative is the reversal of urbanization, to restore an area to its original state, "repristination" using the italianism. But, is it possible to propose the reversion of the excess of urbanization as a general strategy? Is it achievable to "repristinate" urban land to a previous rural state? It is true that there is little experience in this regard, and the few that it exist (i.e. the partial dismantling of urban development at the Natural Park of El Saler in Valencia) have been extremely expensive and lengthy. Its success and viability will depend largely on the stage of urbanization (administrative phase, legal and economic stage, architectural works already done), but by all means this option should not be ruled out.

In the first step, when the land is just planned, the costs of reversal are quite low, reduced in the worst case to indemnify for technical projects. When the stage of management has been 
completed, complications arise exponentially. If it the new plots, resulting in this phase, have been entered into the Land Registry, it is still possible to retrace them but social conflict and the amount of compensations may make it inadvisable.

If the land has been urbanized and we must proceed with demolitions, compensation will extremely high, probably beyond any affordable hypothesis, so this option may only be undertaken in cases of exceptional value, or when the property has failed to fulfil its obligations or commitments. Finally, it makes little or no sense to talk about "deurbanization" if the land has been occupied by buildings. Strategies of this type known as Urban Renewal are only feasible when the capital gains make them profitable.

\section{CASE STUDIES}

We have selected two case studies, somehow related, that show the impact of hyperurbanization, as well as the possibilities of deurbanization or reuse. The first one is the construction of the ZAL (acronym for "Zona de Actividades Logísticas", Logistics Activities Zone) of the Port of Valencia in the district of La Punta (Valencia), and the second one is the development of the Industrial Park I in Sagunt.

\subsection{The ZAL at La Punta}

The construction of the Logistics Activities Zone (hereinafter ZAL) of the Port of Valencia entailed an intense social conflict, the transgression of planning, a nonsense from the beginning to the end. The location were the ZAL has been developed was one of the best orchard lands in the area surrounding the city of Valencia. In the Master Plan of 1988, this area was protected at the highest level: land not to be developed, for agricultural use, with special protection. All in vain when the real state gale fell on Valencia, a consortium of several Public Administrations (the Port Authority, the City Council, the Generalitat, autonomous government and SEPES (State Society for the Promotion and Equipment Land a public agency under the Ministry of Development), decided in 1994 to carry out the development of a logistic zone for the Port of Valencia at La Punta.

The plan was approved in 1999, braving from the beginning a very strong social opposition, an alliance in which they joined the farmers in the area, environmental movements, academics, professionals, artists and intellectuals, neighbourhood and social associations. Useless actions, unfortunately the battle was lost, and today the ZAL lies perfectly empty, occupying a total area of 68.3 hectares where not a single industry or warehouse has settled in.

In 2013 the Supreme Court, responding to the appeal made, issued a sentence repealing the operation, although the judgment itself indicates that this is due to formal issues, not to substantive considerations, and suggest that the plan might be redraft the plan again. Two years later, the same court confirmed its decision, when the works or urbanization were fully completed. Today, the ZAL is nothing. A sea of asphalt and weeds, no logistics bays, no activity, a mirage. A fenced area, surrounded, guarded and deserted.

What impacts has this development? The first one is the disappearance of the best agricultural land, and the expulsion of the farmers who lived there. Seventy hectares to add to the constant reduction of agricultural land of the highest quality. A huge social, administrative and economic cost, impacts that with the expanded definition of sustainability we have adopted cannot be underestimated. An example of the worst squandering of public resources and a sample of an authoritarian way of doing things that must pass into a sad chapter of history.

Against this situation, several alternatives have been publicize. The new President of the Port of Valencia, despite the political change occurred in May 2015, insists on the mainte- 


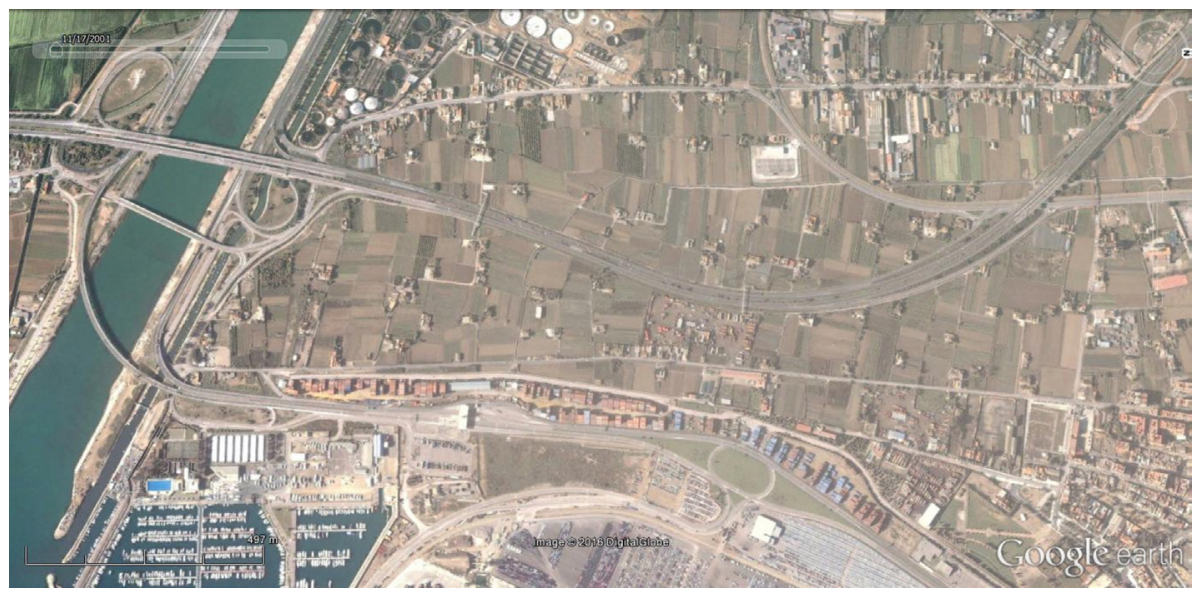

Figure 1: ZAL (17th November 2001).

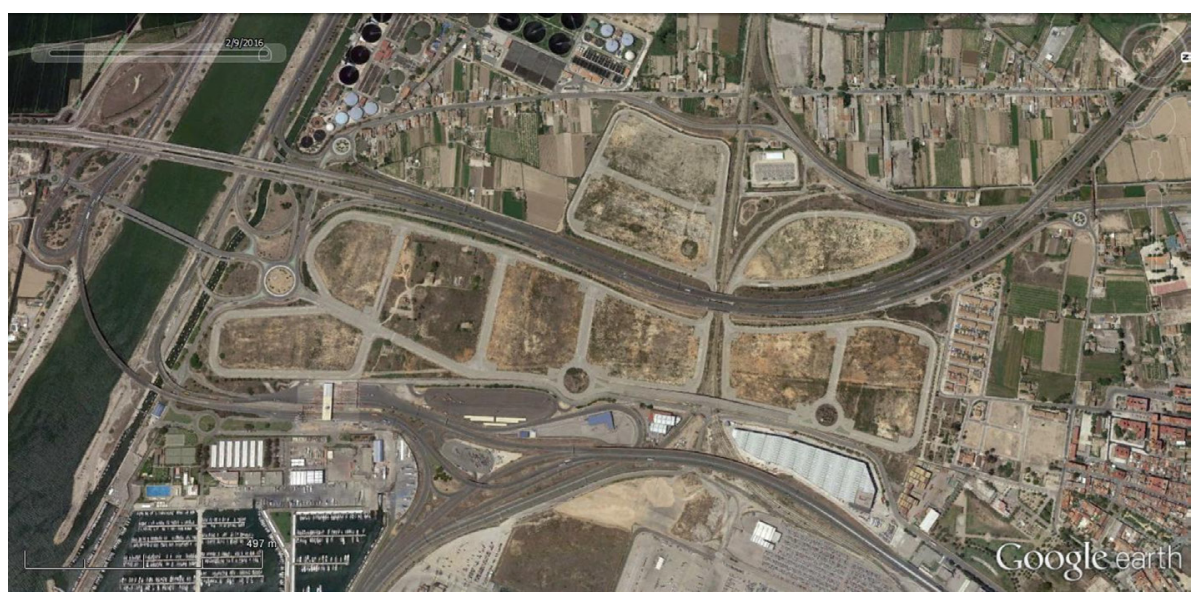

Figure 2: ZAL (3rd July 2014).

nance of the operation, as it was conceived [11]. On the other hand, the new municipal Administration of the city has issued a compromise proposal in which the east area, adjacent to the port, would maintain tertiary uses while the west part of the development would be transformed to host urban agricultural gardens [12]. We consider this alternative timid and inadequate. Discarded the repristination of this land of exceptional value, perhaps the most viable alternative is the removal of the ZAL to the Parc Industrial I of Sagunt.

\subsection{Parc industrial I (Sagunt)}

South of the industrial city of Sagunt a development named "Parc Industrial I" (Industrial Park I) has been promoted and jointly built by the Generalitat and SEPES. The figures of the project were dizzying, an area of 1,448.50 hectares, a budget of 252 million euros, and a forecast of 30,000 jobs. The reality is quite different, as of 2016 only three companies had settled in, all three from agribusiness sector. An unmitigated fiasco. 


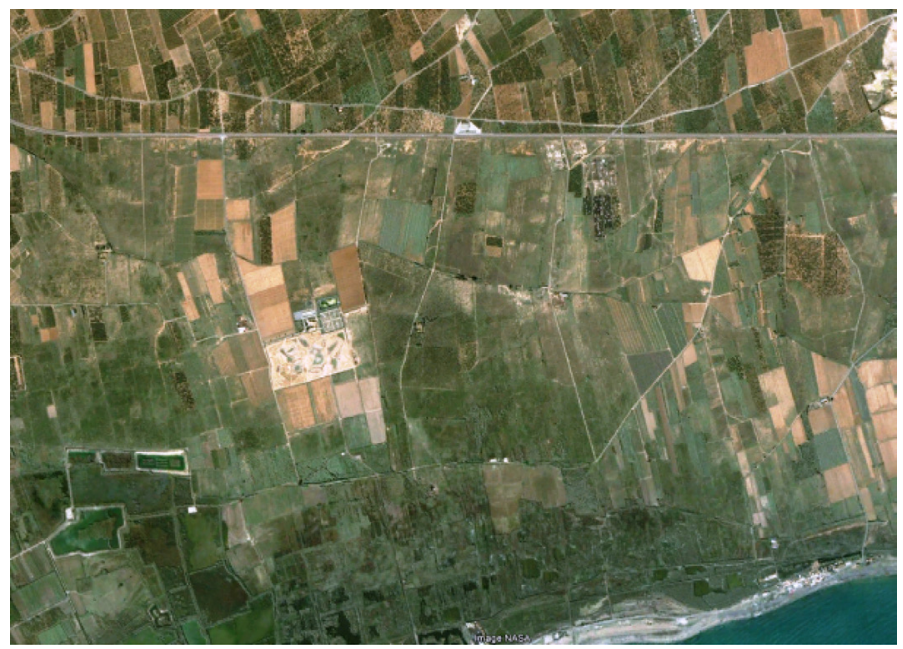

Figure 3. Parc Industrial I (12th September 2002)

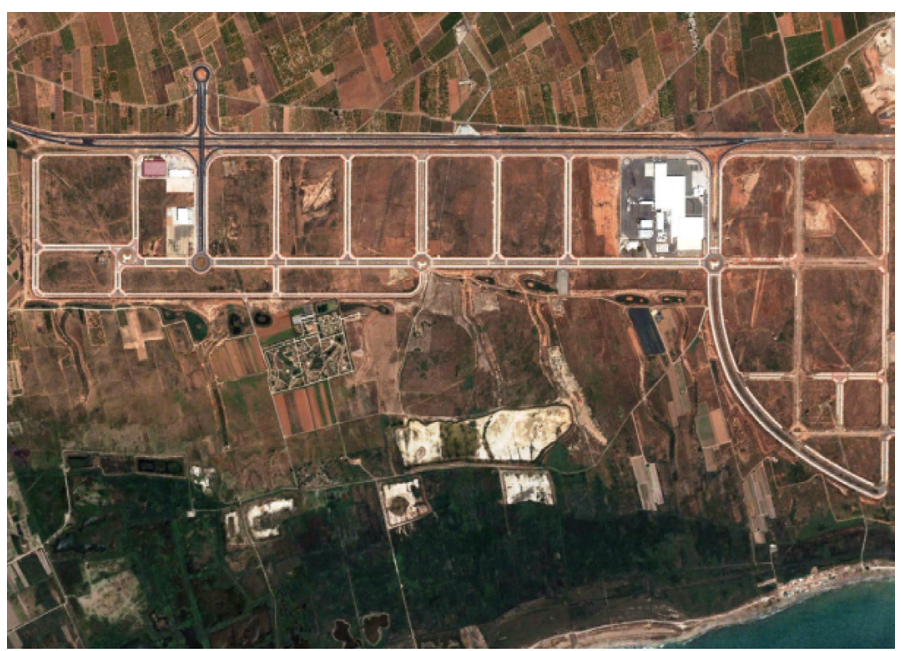

Figure 4. Parc Industrial I (1st July 2014)

Industrial Park I has been built on land that was agricultural before the developing process began, neighbouring to the marsh of El Moro, an area that was declared by the EU as SPA (Special Protection Area) in the Natura 2000 network in 1996 [13]. It is true that these wetlands were considered unhealthy and disease outbreaks so they suffered a gradual drying and conversion to farmland. The Marsh of El Moro did not escape these threats but after being declared as SPA (Special Protection Area) it has become an important space for a large number of both migratory and resident birds. In addition to the impact on a vulnerable area, the project of Park Industrial I can be challenged for its excessive size, and because once built, and in view of his failure, is not being used as an alternative to the ZAL of the Port of Valencia, as ab initio had raised some authors Olmos [14]. 


\section{CONCLUSION}

The vast extension of unconsolidated or empty urban land produced in the fin-de-siècle construction boom (1996-2007) implies environmental and social impacts that require immediate public action. It is impossible to remain indifferent to the costs that this empty city entails. However, there is no single viable alternative for reducing those diseconomies and collateral damages. Government intervention should combine the strategies that have been exposed (maintenance, reuse, and deurbanization repristination). As a prerequisite the development of a detailed, municipality to municipality, operation by operation, must be carried out, in order to account for their implementation stage, their owners, and the burdens and costs of a possible reversion.

\section{REFERENCES}

[1] Naredo, J.M., El modelo inmobiliario español y sus consecuencias, Icaria: Barcelona, p. 51, 2011.

[2] Gaja i Díaz, F., Reparar los impactos de la burbuja constructora. Scripta Nova. Revista Electrónica de Geografía y Ciencias Sociales, 19(517), 2015, availabel at http://www. ub.es/geocrit/sn/sn-517.pdf

[3] Kessler Report, PE 346 773, The European Parliament, 6th July 2004, available at www.europarl.europa.eu/meetdocs/2004_2009/.../dt/.../536421es.pdf

[4] Fourtou Report, PE 362.800v02-00, The European Parliament, 5th December 2005, available at http://www.abusos-no.org/Activities/Fourtou.final.es.htm

[5] Auken Report, PE416.354v02-00, The European Parliament, 20th February 2009, available at http://habitat.aq.upm.es/boletin/n40/auken.pdf

[6] Sostenibilidad en España 2014; Observatorio de la Sosteniblidad en España (OSE), Alcalá de Henares, p. 92, 2015, available at http://www.observatoriosostenibilidad.com/ sostenibilidad-en-espana-2014/

[7] European Union, European Environment Agency (EEA). Corinne Land Cover, Copenhagen, available at http://www.eea.europa.eu/publications/COR0-landcover

[8] Burriel de Orueta, E.L., El estallido de la burbuja inmobiliaria y sus efectos en el territorio. In eds. J.M. Albertos Puebla \& J.L. Sánchez Hernández, Geografía de la crisis económica en España, Publicaciones de la Universidad de Valencia, Valencia, pp. 101-140, 2014.

[9] Vazquez, C., Una bolsa de 80.000 hectáreas de suelo urbanizable sin futuro cierto. El País, 27th January 2013, available at Http://ccaa.elpais.com/ccaa/2013/01/27/valencia/1359313463_322033.html

[10] Gaja i Díaz, F., Reparar los impactos de la burbuja constructora. Scripta Nova. Revista Electrónica de Geografía y Ciencias Sociales, 19(517), 2015, available at http://www. ub.es/geocrit/sn/sn-517.pdf

[11] Valero, D., Aurelio Martínez dice que revertir la ZAL supondría pagarla a precio de Manhattan. Valencia Plaza, 3rd October, 2015, available at http://valenciaplaza.com/ Aurelio-Martnez-dice-que-revertir-la-ZAL-supondria-pagarla-a-precio-de-Manhattan

[12] Alvarez, F., Del Salvem La Punta a la defensa de la ZAL. El Mundo, 24th January 2016, available at http://www.elmundo.es/comunidad-valenciana/2016/01/24/56a3be87e270 4e752d8b4622.html

[13] Ministerio de Agricultura, Alimentación y Medio ambiente. Espacios Protegidos, ZEPA Marjal de El Moro, ES0000470 available at http://www.magrama.gob.es/es/biodiversidad/temas/espacios-protegidos/red-natura-2000/zepa_cvalenciana.aspx

[14] Olmos, J., ¿Por qué no la ZAL en Sagunto? available at http://www.terracritica.org/ articles.php?article_id=248\&idioma=_v 